\author{
${ }^{1}$ Assist. Prof., Dept. of Marketing, \\ Patuakhali Science and Technology \\ University, Bangladesh, \\ towfiqhasan.du@gmail.com
}

ORCID:0000-0002-6370-7877

${ }^{2}$ Assist. Prof., Dept. Accounting and Information Systems, Patuakhali Science and Technology University, Bangladesh, sumon.ais@pstu.ac.bd

ORCID: 0000-0001-7246-8487

${ }^{3}$ Assist. Prof., Dept. of Management Studies, Patuakhali Science and Technology University, Bangladesh, tareq.islam.du@gmail.com

ORCID: 0000-0003-1187-649X

${ }^{4}$ Assist. Prof., Dept. of Finance and Banking, Patuakhali Science and Technology University, Bangladesh, sabbir.fbk@pstu.ac.bd

ORCID:0000-0002-4843-1251

Corresponding Author:

Abdulla Al-Towfiq Hasan,

Dept. of Marketing, Patuakhali Science and Technology University, Bangladesh, towfiqhasan.du@gmail.com

Submitted: 15/10/2021

Revised: 1/12/2021

Accepted: 16/12/2021

Online Published: 25/12/2021

Citation: Hasan, A.A., \& Sumon, S.M., \&Islam, M.T., \&Hossain, M.S.,Factors influencing online shopping intentions: The mediating role of perceived enjoyment, tujom (2021) 6 (3):239-253, doi: https://doi.org/10.30685/tujom.v6i3.132

\title{
Factors influencing online shopping intentions: The mediating role of perceived enjoyment
}

\author{
Çevrimiçi alışveriş niyetlerini etkileyen faktörler: Algılanan keyfin \\ aracilık rolü
}

\author{
Abdulla Al-Towfiq Hasan ${ }^{1}$ \\ Md. Tariqul Islam ${ }^{3}$
}

\author{
Shah Mahmud Sumon ${ }^{2}$ \\ Mohammad Sabbir Hossain ${ }^{4}$
}

\begin{abstract}
The study aimed to understand factors influencing customers' online shopping intentions. This study used the technology acceptance model (TAM) and extended it, including social value and perceived enjoyment, to measure customers' intentions in the online shopping context. Three hundred one validated data was collected using personal interviews and the online survey approach through convenience sampling technique from 20 to 60 years old. Subsequently, data were analyzed through PLS-SEM. The measurement model was first examined to determine whether the constructs predict online shopping intentions. After validating the measurement model, the subsequent structural model was analyzed using Smart PLS 3.3.3. The study results revealed that perceived usefulness, attitude, social value, and perceived enjoyment are significant positive predictors of online shopping intentions. However, perceived ease of use insignificantly impacted online shopping intentions. Moreover, this study results showed that perceived enjoyment partially mediates the relationship between perceived usefulness, perceived ease of use, social value, and online shopping intentions. In contrast, the influence of attitude on intentions is insignificantly mediated by perceived enjoyment. This study will provide online e-retailers with insights into how practitioners can influence customers to shop online. Customer behaviour is the result of customers' intentions, built through perceived usefulness, ease of use, attitude, social value, and enjoyment.
\end{abstract}

Keywords: Perceived Usefulness, Perceived Ease of Use, Attitude, Social Value, Perceived Enjoyment, Online Shopping Intentions

Jel Codes: M31

Öz

Çalışmanın amacı, müşterilerin çevrimiçi alışveriş niyetlerini etkileyen faktörleri anlamaktı. Bu çalışma, teknoloji kabul modelini (TAM) kullanmış ve onu sosyal değer ve algılanan zevk dahil olmak üzere, müşterilerin çevrimiçi alışveriş bağlamındaki niyetlerini ölçmek için genişletmiştir. 20 ila 60 yaşları arasında kolayda örnekleme tekniği ile kişisel görüşmeler ve çevrimiçi anket yaklaşımı kullanılarak toplam 301 doğrulanmış veri toplanmıştır. Daha sonra veriler PLS-SEM ile analiz edildi. İlk olarak, yapıların çevrimiçi alışveriş niyetlerini tahmin edip edemeyeceğini belirlemek için ölçüm modeli incelenmiştir. Ölçüm modeli doğrulandıktan sonra, sonraki yapısal model Smart PLS 3.3.3 kullanılarak analiz edildi. Çalışma sonuçları, algılanan fayda, tutum, sosyal değer ve algılanan keyfin çevrimiçi alışveriş niyetlerinin önemli pozitif yordayıcıları olduğunu ortaya koymuştur. Bununla birlikte, algılanan kullanım kolaylığı, çevrimiçi alışveriş niyetlerini önemsiz bir şekilde etkiledi. Ayrıca, bu çalışma sonuçları, algılanan zevkin algılanan fayda, algılanan kullanım kolaylığı, sosyal değer ve çevrimiçi alışveriş niyetleri arasındaki ilişkiye kısmen aracılık ettiğini göstermiştir. Tersine, niyetin niyetler üzerindeki etkisi, algılanan zevk tarafından önemsiz bir şekilde aracılık eder. Bu çalışma, çevrimiçi e-perakendecilere, uygulayıcıların müşterileri çevrimiçi alışveriş yapma konusunda nasıl etkileyebileceklerine ilişkin bilgiler sağlayacaktır. Müşteri davranışı, müşterilerin algılanan kullanışlılığı, kullanım kolaylığı, tutumu, sosyal değeri ve keyfi yoluyla oluşturulan müşterilerin niyetlerinin bir sonucudur.

Anahtar Kelimeler: Algılanan Fayda, Algılanan Kullanım Kolaylığı, Tutum, Sosyal Değer, Algılanan Zevk, Online Alışveriş Amaçları

JEL Kodları: M31 


\section{Introduction}

The emergence of e-commerce has enhanced the rapid growth of online shopping. Online shopping is a mechanism by which customers browse, search for, compare, and purchase goods via the internet. The online retail sector has contributed USD 4.2 trillion to the digital economy worldwide in 2020 (Coppola, 2021). Thus, the significance of online shopping has grown in recent years. Furthermore, most people spend their leisure time using online social networking activities, web surfing, and gaming leads them to be accustomed to digital shopping using the internet. Given the potential importance, online business organizations, especially online retailers, are uncovering how they can increase customers' online shopping intentions.

Although customers 'shopping enjoyment and external social pressure (social value) are important determinants of online shopping intentions, this sector has yet to address the aspects of customers' social matter and perceived enjoyment. Undoubtedly, no previous study has assumed that customers' perceived usefulness, ease of use, attitude, and social value towards online shopping intentions are intervened by perceived enjoyment. However, with the high penetration rate of the internet, wireless network, and Smartphone availability, coupled with the growth of consumer purchasing power, there is some evidence that customers having access to online technologies tend to shop online (Gong, Stump, and Maddox 2013). Thus, this study assumed that customers' perceived usefulness, perceived ease of use, attitude, and social value towards online shopping intentions are mediated by customers' perceived enjoyment.

Literature demonstrated that the technology acceptance model (TAM) was widely used to predict customers' intentions towards online shopping (Chiu, Chao-Min, Hua-Yang Lin, Szu-Yuan Sun, and Meng-Hsiang Hsu 2009; (Vijayasarathy 2004). Recently, Chiu et al. (2009) applied TAM to measure customers' loyalty and intentions towards online shopping in research. In their study,(Amin, Rezaei, and Abolghasemi 2014) used TAM and identified that perceived usefulness and ease of use influenced customers' intentions. In line with this, Hsu, Lin, and Chiang (2013) measured the influence of attitude on behavioural purposes. Finally, Wu, Wei, Vivian Huang, Xiayu Chen, Robert M. Davison, and Zhongsheng Hua (2018) investigated the impact of social value on online shopping intentions. However, to the best knowledge, no previous study examined TAM including attitude and social value to predict customers 'online shopping intentions.

The present study modified TAM, considering the variables explained in recent literature as predictors of online shopping intentions. These variables, including attitude (Zendehdel, Paim, and Osman 2015) (Wu et al. 2018) social value (Chen and Zhang 2021), and perceived enjoyment (Patel et al. 2020), potentially predict online shopping intentions. However, these constructs were tested separately in predicting preferences towards online shopping. Even though the previous studies (Sohn, 2017;Tong, 2010;Brizi et al., 2015; Yoon, 2009) used different combinations of these variables, to the best knowledge, no study incorporated all six variables together with such causal relationship among them to understand online shopping intentions.

\section{Literature review}

Customers' acceptance intentions of online purchasing and transactions can be explained through previous research models such as the technology acceptance model (TAM) (Davis,1989), the theory of planned behaviour (TPB) (Ajzen 1991), and the decomposed TPB model (Taylor and Todd 1995). The technology acceptance model (TAM) based on the theory of reasoned action (TRA) indicates that perceived usefulness and ease of use affect the customers' behavioural intentions. In addition, other constructs such as attitude, subjective norms, perceived behavioural control, and perceived value affect behavioural intentions, mainly online shopping intentions (Yoon, 2009; Hasan, A. A., Chhanda Biswas, Moumita Roy, Sonia Akter, and Bapon Chandra Kuri, 2020). Therefore, although TRA is the prominent model for predicting customers' behavioural preferences, the TAM can be a powerful model for understanding customers' intentions to shop online. 


\section{Online shopping intentions}

Behavioural intentions, mainly online shopping intentions, refer to predisposed determination to perform a specific performance. It is considered a consequence of customers' attitudes, social value, and perceived ease, usefulness, and enjoyment. Lim, Yi Jin, Abdullah Osman, Shahrul Nizam Salahuddin, Abdul Rahim Romle, and Safizal Abdullah (2016) explained that customers' online shopping intentions outcome of some intrinsic factors such as desires, novelty-seeking, prestige, and entertainment. $\mathrm{Hu}, \mathrm{Xi}$, Qian Huang, Xuepan Zhong, Robert M. Davison, and Dingtao Zhao (2016) also demonstrated that customers' shopping intention results from customers' experiences, attitudes, and socialization. In addition, in their research, Cheema, Umair, Muhammad Rizwan, Rizwan Jalal, Faiza Durrani, and Nawal Sohail (2013) claimed that motivations such as freedom of choice, purchasing flexibility, and time-saving attributes determine customers' online shopping intentions.

\section{Perceived usefulness and online shopping intentions}

Online shopping provides different advantages such as comparison-shopping, access to necessary information, minimized shopping time, improved life and lifestyle. Perceived usefulness is the degree to which a person believes that using a strategic system would amplify their accomplishment (Davis 1989). Based on these, perceived usefulness is defined as the degree to which a human believes that their task performance would be improved by using a specific system (Davis 1989). Customers' perceived usefulness of online shopping is considered an innovation characteristic that helps to provide more efficient approaches to measure customers' online shopping intentions.

Prior literature demonstrated the effect of perceived usefulness on intentions in several sectors (Purnawirawan, Nathalia, Patrick De Pelsmacker, and Nathalie Dens, 2012). Tandon, Urvashi, Ravi Kiran, and Ash N. Sah (2016) explained that perceived usefulness significantly impacts online shopping intentions. In addition, Lim et al. (2016) identified that perceived improved life and lifestyle determine the online shopping intentions. Moreover, in research, Sohn (2017)found that perceived usefulness is a key to forming preferences towards online shopping. Therefore, it was hypothesized that:

\section{H: Perceived Usefulness significantly affects online shopping intentions.}

\section{Perceived ease of use and online shopping intentions}

"Ease of use" is defined as the individual's belief that taking advantage of new technology is liberated from exertion (Kucukusta, Deniz, Rob Law, Alia Besbes, and Patrick Legohérel, 2015). Ozturk, Ahmet Bulent, Anil Bilgihan, Khaldoon Nusair, and Fevzi Okumus (2016) argued that perceived ease of use represents a mechanism by which a system is perceived to be easy to understand, analyze, or function, leading shoppers to intend online shopping.

Previous studies demonstrated that customers' perceptions of ease of use and flexibility of online shopping influence customers' intentions towards online shopping (Ashraf et al., 2016; Kim \& Song (2010) described that customers' perceptions of the easiness of shopping and time-saving criteria strongly determine the customer's online shopping intentions. In addition, $\mathrm{Hu}$ et al. (2009) explained that the perceived ease of use is significantly related to online shopping intentions. Moreover, Yoon (2009) found that perceived ease of use is a significant predictor to explain online shopping intentions. Thus, it was hypothesized that:

\section{$\mathbf{H}_{2}$ : Perceived ease of use significantly affects online shopping intentions.}

\section{Attitude and online shopping intentions}

Attitude discussed in the TAM model defines a positive or negative fleeing of performing a specific behaviour(Yoon 2009). Fishbein and Ajzen (1975)developed an attitude in the reasoned action (TRA) model to predict behavioural intentions. Attitude refers to how a person favourably or unfavourably evaluates a particular behaviour. Many studies have proved that a positive attitude induces high 
intentions to perform a specific behaviour (Hsu, Chin-Lung, Judy Chuan-Chuan Lin, and Hsiu-Sen Chiang, 2013; Yoon, 2009).

Prior studies showed that attitudes towards online shopping directly affect online shopping intentions (Khare \& Rakesh, 2011;Hsu et al., 2013). Abdul-Muhmin, (2010) also explained that attitude is one of the significant factors helping determine customers' behavioural intentions towards online shopping. While evaluating consumer attitudes towards online shopping intentions, some attributes (e.g., online shopping is a good idea, online shopping is enjoyable, and online shopping is fantastic) affect online shopping intentions. In addition, Zendehdel et al. (2015) confirmed that customers' positive attitudes towards online shopping substantially impacted online shopping intentions. This study aims to investigate the relationship between attitude and online shopping intentions based on this literature. Therefore, it was hypothesized that:

$\boldsymbol{H}_{3}$ : Attitude significantly affects online shopping intentions.

\section{Social value and online shopping intentions}

The social value derived from an alternative association with specific social groups is perceived utility. $\mathrm{Wu}$ et al. (2018)argued that social value similar to subjective norm construct refers to perceived social pressure to approve or disapprove of a behaviour style. Social value reflects external social pressure from referent groups that consist of family members, friends, neighbours, colleagues, or peers (Hu et al., 2016). Thus, customers' online shopping intention is dominated by referents' opinions.

Previous literature demonstrated that social value is one of the most dominant factors influencing customers' behavioural intentions, mainly online shopping intentions (Chen \& Zhang, 2021). Furthermore, Oliver \& Lee (2010) explained that referents and social groups seemingly influence customers' online shopping intentions. Moreover, social approval and social acceptance constitute customers' motivations for online shopping (Brizi, Ambra, Mauro Giacomantonio, Birga M. Schumpe, and Lucia Mannetti, 2015). Thus, the current study proposes the following hypothesis:

$H_{4}$ : Social value significantly affects online shopping intentions.

\section{Perceived enjoyment and online shopping intentions}

Perceived enjoyment refers to an individual's intrinsic motivation to use a particular system. Rouibah, Kamel, Paul Benjamin Lowry, and Yujong Hwang (2016) and Hasan, Abdulla Al-Towfiq (2021) explained that most customers accept new technologies and new approaches because they can provide inherent benefits such as entertainment, enjoyments, etc.

Few previous studies examined the relationship between perceived enjoyment and behavioural intentions. More specifically, Cheema et al. (2013) examined the effect of perceived enjoyment on online shopping intentions. Also, Tong (2010) explained that perceived enjoyment aspects such as excitement and fun significantly influence online shopping intentions. Moreover, Patel, Vipul, Kallol Das, Ravi Chatterjee, and Yupal Shukla (2020) found that perceived enjoyment significantly predicts shopping intention. Therefore, it was hypothesized that:

$H_{5}$ : Perceived enjoyment significantly affects online shopping intentions

\section{Perceived usefulness, perceived ease of use, attitude, social value, and perceived enjoyment}

Although no previous study examined the effect of perceived usefulness, perceived ease of use, attitude, and social value on perceived enjoyment, several studies investigated the casual relationship among them in several contexts (Ramayah \& Ignatius, 2005;Teo \& Noyes, 2011). Abdullah, Ward, and Ahmed (2016) examined the relationship between perceived usefulness, perceived ease of use, attitude, and enjoyment. In a study, Pitafi, Kanwal, and Khan (2020)identified that perceived ease of use and social enjoyment is positively correlated. Ke, Chih-Horng, Huey-Min Sun, Yuan-Chi Yang, and Huey-Min Sun (2012) mentioned that perceived usefulness and enjoyment is significantly correlated. Dickinger, Arami, and Meyer (2008) identified that attitude and perceived happiness is particularly associated. Finally, Jolly, Eshin, Diana I. Tamir, Bethany Burum, and Jason P. Mitchell (2019) described that social value is 
positively related to enjoyment. Based on these studies, it can be inferred that perceived usefulness, ease of use, attitude, and social value influence perceived happiness. There, this study proposes the following hypothesis.

$H_{6:}$ Perceived usefulness significantly affects perceived enjoyment.

H:: Perceived ease of use significantly affects perceived enjoyment.

Hs: Attitude significantly affects perceived enjoyment.

H9: Social value significantly affects perceived enjoyment.

\section{The mediating role of perceived enjoyment}

The mediator is the third variable that intervenes in the relationship between the exogenous and endogenous variables. Although no previous study examined the mediating effect of perceived enjoyment in the relationship between perceived usefulness, perceived ease of use, attitude, and social value, and online shopping intentions, Holdack, Eric, Katja Lurie-Stoyanov, and Harro Fabian Fromme (2020) measured the mediating effect of perceived enjoyment in the link between perceived ease of use and attitude. Also, Wang, Yi-Shun, Hsin-Hui Lin, and Yi-Wen Liao (2012) identified that perceived enjoyment significantly mediates the association between personality traits and intentions. In addition, Jin (2010) measured the mediating role of entertainment on educational outcomes. So, Kim and Oh (2020) tested the mediating part of perceived enjoyment. Moreover, Giao, Vuong, and Quan (2020) examined the mediating role of perceived fun on customers 'online shopping loyalty. Thus, it is pertinent to investigate the mediating effect of perceived value in the relationship between perceived usefulness, ease of use, attitude, social value, and online shopping intentions. Therefore, this study proposes the following hypothesis:

H10: Perceived enjoyment partially mediates the influence of perceived usefulness on online shopping intentions.

H11: Perceived enjoyment partially mediates the influence of perceived ease of use on online shopping intentions.

H12: Perceived enjoyment partially mediates the influence of attitude on online shopping intentions.

H13: Perceived enjoyment partially mediates the influence of social value on online shopping intentions.

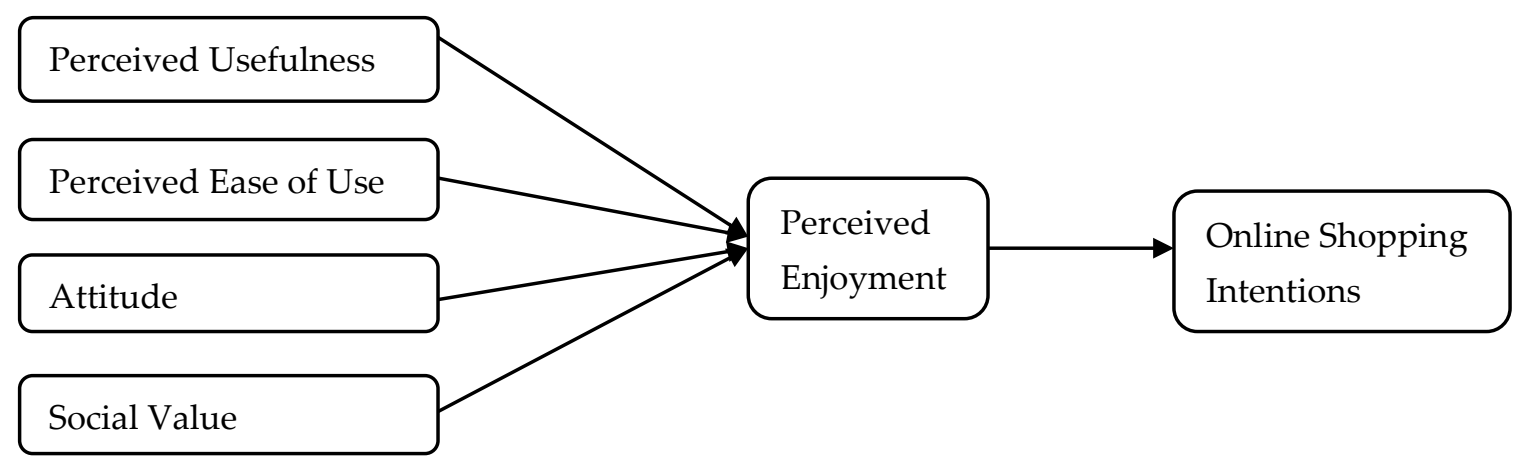

Figure 1. Proposed research framework

Source: Authors

\section{Design and method}

\section{Measures}

All study constructs were measured using structured questionnaires borrowed from previous studies and modified to fit the current research context. Perceived usefulness was measured using three items adapted from Manis \& Choi (2019). Three things suggested by Manis \& Choi (2019) also were adapted to measure perceived ease of use. The attitude was measured through three validated scales mentioned by Manis \& 
Choi (2019) adapted to the research context. Three measurement scales measured social value and online shopping intentions for each construct, adopted from Lin \& Huang (2012) and modified to the current research context. Lastly, three items of perceived enjoyment were borrowed from Kim et al. (2013)and modified to fit this study context.

\section{Sampling and data collection}

The survey data was collected using a convenience sampling technique from customers aged between 20 and 60 years. The survey was conducted using previously validated structured questionnaires through $25 \%$ personal interviews and $75 \%$ online survey sending Google drive links to respondents. A total of 1000 respondents were approached and got 324 responses. Among these responses, 23 were excluded due to extreme value. Consequently, 301 valid responses were used for data analysis supported by Osborne \& Costello (2004).

\section{Data analysis}

Anderson \& Gerbing (1988) suggested the two-step approach was used to examine the confirmatory factor analysis to determine whether the observed variables reflect the latent constructs using the covariance matrix. Consequently, the measurement and structural models were analyzed using Smart PLS 3.3.3. First, the measurement model was analyzed using factor loadings, Cronbach Alpha, composite reliability, average variance extracted (AVE). Subsequently, the structural model was analyzed through bootstrapping with 1000 subsamples. Moreover, cross-validated redundancy (Q2) and effect size (f2) were analyzed to measure the model's predictive relevance.

\section{Findings and discussion}

Table 1 shows the demographic profiles of the respondents. $53.48 \%$ (161) were male, and $46.52 \%$ (140) were female among the valid respondents. Most of the respondents $(37.20 \%)$ were in the age range between 20 and 30, and their mean age was 35.38 years. In terms of income, most respondents' (61.47\%) income was in between BDT (Bangladesh taka) 20000 and BDT 50000. approximately, 42.85\% of respondents have 1 to 3 years of online shopping experience.

Table 1: Demographic profile of respondents $(n=301)$

\begin{tabular}{lcc}
\hline Variables & $\mathrm{n}$ & Percentage (\%) \\
\hline Gender & & \\
$\quad$ Male & 161 & 53.48 \\
$\quad$ Female & 140 & 46.52 \\
Age (years) & & \\
20 to 30 & 112 & 37.20 \\
31 to 40 & 99 & 32.89 \\
41 to 50 & 66 & 21.93 \\
51to 60 & 24 & 7.98 \\
The mean age is 35.38 years & & \\
Monthly income (BDT) & & \\
Below 20000 & 84 & 27.90 \\
20000-50000 & 185 & 61.47 \\
Above 50000 & 32 & 10.63 \\
Online Shopping experience (years) & & \\
Below 1 & 78 & 25.92 \\
1-3 & 129 & 42.85 \\
Above 2 & 94 & 31.23 \\
\hline
\end{tabular}

\section{Measurement model}

The measurement model validated the research model, ensuring convergent validity, discriminant validity, and internal consistency. Cronbach Alpha and composite reliability values were calculated to test the constructs' internal consistency. The following statistics of all Cronbach Alpha and composite reliability values were higher than the recommended thresholds (Bagozzi and Yi 1988). All alpha values ranged between 0.773 and 0.882 , and composite reliability values were 0.868 to 0.926 (see Table 2). The 
average variance extracted (AVE) was calculated to test the convergent validity, and all subsequent AVE values were over 0.5 (see Table 2). Moreover, all the AVE's values exceeded the squared correlation between the corresponding construct and other variables (see Table 3), indicating discriminant validity. Therefore, the convergent and discriminant validity were confirmed before applying the procedures suggested by Fornell \& Larcker (1981).

Table 2: Measurement model results

\begin{tabular}{|c|c|c|c|c|}
\hline Constructs/Items & $\begin{array}{l}\text { Factor } \\
\text { loadings }\end{array}$ & $\begin{array}{l}\text { Cronbach's } \\
\text { alpha }(\alpha)\end{array}$ & $\begin{array}{l}\text { Composite } \\
\text { reliability } \\
\text { (CR) }\end{array}$ & $\begin{array}{l}\text { The average } \\
\text { variance } \\
\text { extracted (AVE) }\end{array}$ \\
\hline \multicolumn{5}{|l|}{ Perceived usefulness } \\
\hline Online shopping would be helpful in my life. & 0.906 & \multirow{3}{*}{0.882} & \multirow{3}{*}{0.926} & \multirow{3}{*}{0.806} \\
\hline Online shopping would improve my life. & 0.929 & & & \\
\hline Online shopping would enhance my lifestyle. & 0.857 & & & \\
\hline \multicolumn{5}{|l|}{ Perceived ease of use } \\
\hline Online shopping would be easy for me. & 0.886 & \multirow{3}{*}{0.865} & \multirow{3}{*}{0.917} & \multirow{3}{*}{0.787} \\
\hline Online shopping makes it easy to get what I want to purchase. & 0.906 & & & \\
\hline Online shopping would be flexible to shop. & 0.869 & & & \\
\hline \multicolumn{5}{|l|}{ Attitude } \\
\hline Online shopping is a good idea. & 0.821 & \multirow{4}{*}{0.779} & \multirow{3}{*}{0.872} & \multirow{3}{*}{0.694} \\
\hline I like Online shopping. & 0.884 & & & \\
\hline Online shopping is enjoyable to me. & 0.792 & & & \\
\hline \multicolumn{4}{|l|}{ Social value } & \\
\hline Online shopping would help me to feel acceptable. & 0.827 & \multirow{3}{*}{0.788} & \multirow{3}{*}{0.877} & \multirow{3}{*}{0.704} \\
\hline Online shopping would make me a good impression on other people. & 0.900 & & & \\
\hline Online shopping would give me social approval. & 0.785 & & & \\
\hline \multicolumn{5}{|l|}{ Perceived enjoyment } \\
\hline Online shopping would be enjoyable. & 0.876 & \multirow{3}{*}{0.799} & \multirow{3}{*}{0.882} & \multirow{3}{*}{0.713} \\
\hline Online shopping would be interesting to me. & 0.863 & & & \\
\hline Online shopping would enhance my excitement. & 0.793 & & & \\
\hline \multicolumn{5}{|l|}{ Online shopping intentions } \\
\hline I intend to continue to shop online in the future. & 0.835 & \multirow{3}{*}{0.773} & \multirow{3}{*}{0.868} & \multirow{3}{*}{0.687} \\
\hline I intend to purchase from online sellers in the future. & 0.808 & & & \\
\hline I intend to continue online shopping next few years. & 0.843 & & & \\
\hline
\end{tabular}

\section{Structural model}

After validating the measurement model, researchers conducted a structural model through a structural equation modelling approach (SEM), testing the proposed hypothesis using Smart PLS 3.3.3. Before testing the hypothesis, the model's fitness measurement is required. Thus, the model's predictive relevance is measured through cross-validated redundancy $\left(\mathrm{Q}^{2}\right)$ suggested by Henseler and Sarstedt (2013). $Q^{2}$ is measured when the model fitness index is not appropriate due have different characteristics between valid and valid models. Table 4 shows the $\mathrm{Q}^{2}$ values of PE (perceived enjoyment) and OSI (online shopping intentions) greater than zero suggesting the model's predictive relevance Henseler et al. (2009). The effect size was measured using $f^{2}$. Effect size $\left(f^{2}\right)$ calculates the quantitative effect of independent variable/s on dependent variable/s with the unity of the variation of $R^{2}$. Cohen (1988) suggests the following formula to compute the effect size.

Effect size $f^{2}=\frac{R^{2} \text { Inclusive }-R^{2} \text { Exclusive }}{1-R^{2} \text { Inclusive }}$ 
Table 3: Results of discriminant validity

\begin{tabular}{ccccccc}
\hline & PU & PEOU & ATT & SV & PE & OSI \\
\hline PU & $\mathbf{0 . 8 9 8}$ & & & & & \\
PEOU & 0.204 & $\mathbf{0 . 8 8 7}$ & & & & \\
ATT & 0.259 & 0.393 & $\mathbf{0 . 8 3 3}$ & & & \\
SV & 0.169 & 0.488 & 0.283 & $\mathbf{0 . 8 3 9}$ & & \\
PE & 0.385 & 0.471 & 0.338 & 0.364 & $\mathbf{0 . 8 4 5}$ & $\mathbf{0 . 8 2 9}$ \\
OSI & 0.411 & 0.472 & 0.402 & 0.472 & 0.577
\end{tabular}

Notes: $\mathrm{PU}=$ perceived usefulness, $\mathrm{PEOU}=$ perceived ease of use, $\mathrm{ATT}=$ attitude, $\mathrm{SV}=$ social value, $\mathrm{PE}=$ perceived enjoyment, $\mathrm{OSI}$ $=$ online shopping intentions

Table 4: Blindfolding results

\begin{tabular}{cccc}
\hline Total & SSO & SSE & Q $^{2}(=1-S S E / S S O)$ \\
\hline PE & 903 & 700.665 & 0.224 \\
\hline OSI & 903 & 618.938 & 0.315 \\
Notes: PE = perceived enjoyment, OSI $=$ online shopping intentions & & \\
\hline
\end{tabular}

Table 5 shows the $f^{2}$ value of perceived usefulness, perceived ease of use, attitude, social value, and perceived enjoyment on online shopping intentions, respectively $0.05,0.01,0.02,0.07$, and 0.13 . Table 6 also shows the $f^{2}$ value of perceived usefulness, perceived ease of use, attitude, and social value on perceived enjoyment, respectively $0.10,0.09,0.01$, and 0.02 . These reflect a small effect size as Cohen (1988) suggested that the value of $0.02,0.15$, and 0.35 or above represent small, medium, and large effect sizes.

Table 5: Effect size of latent variables on online shopping intentions

\begin{tabular}{ccc}
\hline Latent variables & $f^{2}$ & Decision \\
\hline PU & 0.05 & Small \\
PEOU & 0.01 & Small \\
ATT & 0.02 & Small \\
SV & 0.07 & Small \\
PE & 0.13 & Small
\end{tabular}

Notes: $\mathrm{PU}=$ perceived usefulness, $\mathrm{PEOU}=$ perceived ease of use, $\mathrm{ATT}=$ attitude, $\mathrm{SV}=$ social value, $\mathrm{PE}=$ perceived enjoyment

Table 6: Effect size of perceived usefulness, perceived ease of use, attitude, and social value on perceived enjoyment

\begin{tabular}{ccc}
\hline Latent variables & $f^{2}$ & Decision \\
\hline PU & 0.10 & Small \\
PEOU & 0.09 & Small \\
ATT & 0.01 & Small \\
SV & 0.02 & Small
\end{tabular}

Notes: $\mathrm{PU}=$ perceived usefulness, $\mathrm{PEOU}=$ perceived ease of use, $\mathrm{ATT}=$ attitude, $\mathrm{SV}=$ social value

Table 7 and Figure 2 shows the hypothesis's path coefficients, t-statistics, p-value, and decisions. The relationship between perceived usefulness and online shopping intentions (H1) was found significant $(\beta=$ $0.190, t=3.283, p=0.001)$, supporting H1. However, the perceived ease of use was insignificantly related to online shopping intentions (H2) $(\beta=0.118, t=1.814, p=0.070)$; thus, it does not support H2. The strength of the relationship between attitude and online shopping intentions (H3) was found significant $(\beta=0.134, t=$ 2.713, $p=0.007)$, which supportsH3. Social value was found significantly related to online shopping intentions $(\mathrm{H} 4)(\beta=0.229, t=4.283, p=0.000)$, supporting $\mathrm{H} 4$. The direct impact of perceived enjoyment on online shopping intentions (H5) was found significant $(\beta=0.319, t=5.090, p=0.000)$, which supports H5. 
In addition, Table 7 revealed that perceived usefulness was significantly related to perceived enjoyment (H6) $(\beta=0.272, t=4.902, p=0.000)$, which consequently supportsH6. The relationship between perceived ease of use and enjoyment (H7) was significant $(\beta=0.306, t=5.252, p=0.000)$, supporting H7. The results also revealed that attitude was significantly related to perceived enjoyment $(\mathrm{H} 8)(\beta=0.108, t=1.993, p=$ 0.047), supporting H8. The strength of association between social value and perceived enjoyment (H9) was found significant $(\beta=0.138, t=2.698, p=0.007)$; thus, it supports H9. Therefore, all antecedents (exogenous variables) significantly affected online shopping intentions (endogenous variables), implying that customers' online shopping intentions are explained by customers' perceived usefulness, ease of use, attitude, social value, and enjoyment. Moreover, perceived enjoyment is the consequence of customers' perceived effectiveness, ease of use, attitude, and social value.

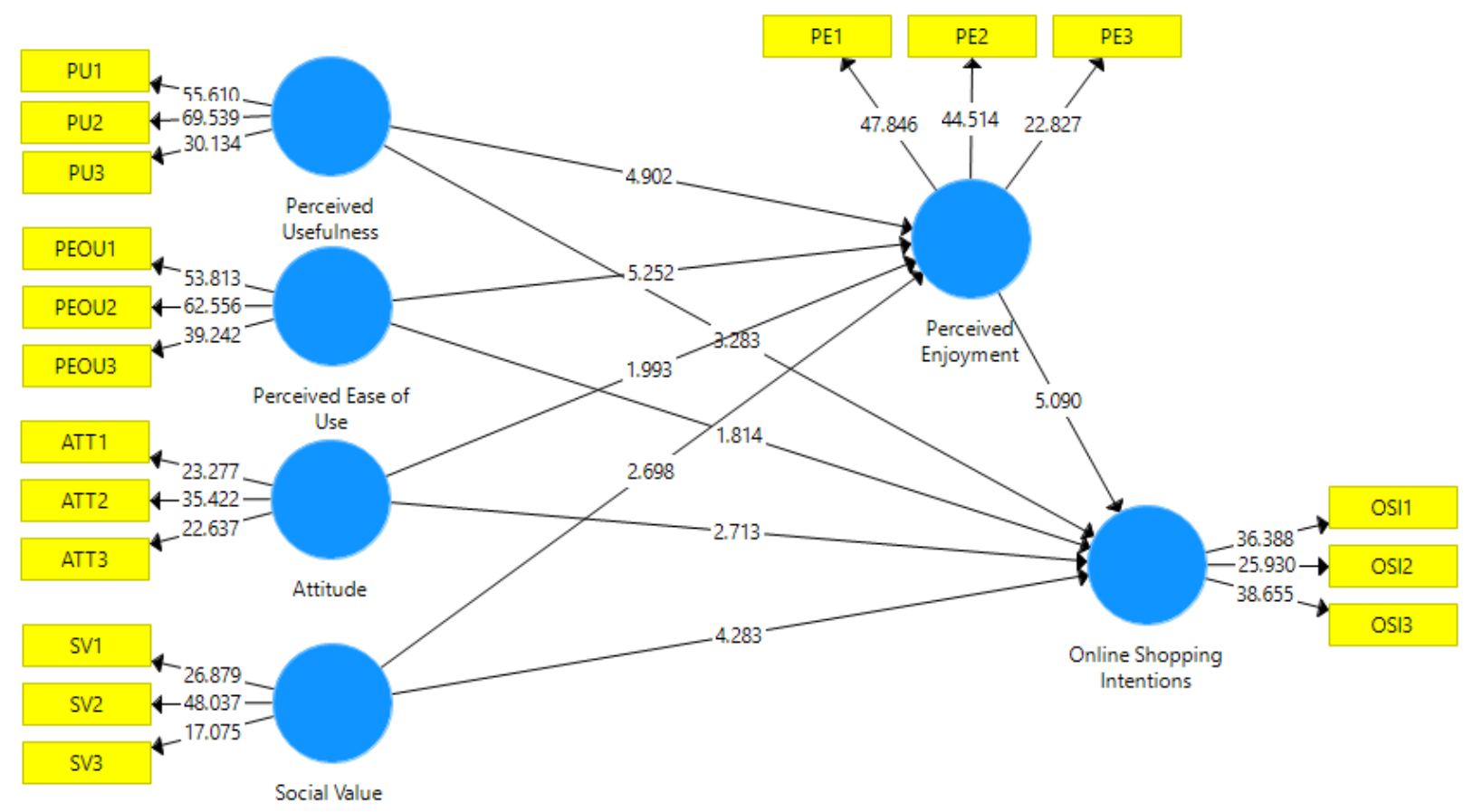

Figure 2: Structural model

Table 7 also shows the results of mediating effect of perceived enjoyment. Perceived usefulness, including perceived enjoyment, affected online shopping intentions (H10), was significant $(\beta=0.087, t=3.652, p=$ 0.000 ), indicating the partial mediation. The strength of the relationship between perceived ease of use included perceived enjoyment and online shopping intentions (H11), was found significant $(\beta=0.098, t=$ 3.599, $p=0.000$ ), which indicates the partial mediation. However, the mediating effect of perceived enjoyment in the linkage between attitude and online shopping intentions (H12) was insignificant $(\beta=$ $0.034, t=1.715, p=0.087$ ), indicating complete mediation. The effect of social value, including perceived enjoyment, on online shopping intentions (H13) was significant ( $\beta=0.044, t=2.341, p=0.019)$, suggesting a partial mediation. These results imply that customers' online shopping intentions are not only the effect of perceived usefulness, ease of use, attitude, and social value. Instead, customers' shopping intentions are determined by customers' perceived enjoyment. 
Table 7: Path coefficients and hypothesis testing

\begin{tabular}{|c|c|c|c|c|c|}
\hline Hypothesis & Relationships & Beta & T-Statistics & P-Values & Decisions \\
\hline H1 & $\begin{array}{l}\text { Perceived Usefulness -> Online Shopping } \\
\text { Intentions }\end{array}$ & 0.190 & 3.283 & 0.001 & Supported \\
\hline $\mathrm{H} 2$ & $\begin{array}{l}\text { Perceived Ease of Use -> Online Shopping } \\
\text { Intentions }\end{array}$ & 0.118 & 1.814 & 0.070 & Not Supported \\
\hline H3 & Attitude -> Online Shopping Intentions & 0.134 & 2.713 & 0.007 & Supported \\
\hline $\mathrm{H} 4$ & $\begin{array}{l}\text { Social Value -> Online Shopping } \\
\text { Intentions }\end{array}$ & 0.229 & 4.283 & 0.000 & Supported \\
\hline H5 & $\begin{array}{l}\text { Perceived Enjoyment -> Online Shopping } \\
\text { Intentions }\end{array}$ & 0.319 & 5.090 & 0.000 & Supported \\
\hline H6 & $\begin{array}{l}\text { Perceived Usefulness -> Perceived } \\
\text { Enjoyment }\end{array}$ & 0.272 & 4.902 & 0.000 & Supported \\
\hline $\mathrm{H} 7$ & $\begin{array}{l}\text { Perceived Ease of Use -> Perceived } \\
\text { Enjoyment }\end{array}$ & 0.306 & 5.252 & 0.000 & Supported \\
\hline H8 & Attitude -> Perceived Enjoyment & 0.108 & 1.993 & 0.047 & Supported \\
\hline H9 & Social Value $->$ Perceived Enjoyment & 0.138 & 2.698 & 0.007 & Supported \\
\hline $\mathrm{H} 10$ & $\begin{array}{l}\text { Perceived Usefulness -> Perceived } \\
\text { Enjoyment -> Online Shopping Intentions }\end{array}$ & 0.087 & 3.652 & 0.000 & Supported \\
\hline H11 & $\begin{array}{l}\text { Perceived Ease of Use -> Perceived } \\
\text { Enjoyment }->\text { Online Shopping Intentions }\end{array}$ & 0.098 & 3.599 & 0.000 & Supported \\
\hline H12 & $\begin{array}{l}\text { Attitude }->\text { Perceived Enjoyment }->\text { Online } \\
\text { Shopping Intentions }\end{array}$ & 0.034 & 1.715 & 0.087 & Not Supported \\
\hline H13 & $\begin{array}{l}\text { Social Value -> Perceived Enjoyment -> } \\
\text { Online Shopping Intentions }\end{array}$ & 0.044 & 2.341 & 0.019 & Supported \\
\hline
\end{tabular}

\section{Conclusion, recommendation and limitations}

The present study explored customers' online shopping intentions using TAM and extending it, leaving theoretical and practical implications.

\section{Implications and suggestions}

The present study findings revealed that the relationship between perceived usefulness and online shopping intentions was strong, consistent with prior research across multiple contexts (Purnawirawan et al., 2012;Ventre \& Kolbe, 2020). This relationship helps practitioners understand how online shopping can be helpful to customers because perceived usefulness primarily determines online shopping intentions. However, the association between perceived ease of use and online shopping intentions shows that perceived ease of use insignificantly impacts online shopping intentions. This association was consistent with previous studies in different contexts (Yoon, 2009; Kim et al., 2010; Biswas, Chhanda, Santus Kumar Deb, Abdulla Al-Towfiq Hasan, and Md Shariful Alam Khandakar, 2020). In addition, the present study finds that customers' attitude is a dominating predictor of online shopping intentions, with a strong positive association between them supported by previous studies (Hsu et al., 2013;Akhlaq \& Ahmed, 2015). This finding implies that customers' positive shopping intentions are the consequences of customers' attitudes. Thus, the practitioners must evaluate the customers' attitudes before measuring their intentions.

From the study findings, the relationship between social value and online shopping intentions was positively correlated, aligned with prior study (Hu et al. 2016). This positive correlation indicates that social pressure and the opinions of peers, friends, and family are positive predictors of online shopping intentions. Hence, the practitioners should cultivate social activist groups and opinion leaders to make customers positively intend to shop online. Furthermore, the current study finds that customers' perceived enjoyment is a positive and robust predictor of intentions towards online shopping, supported by previous studies (Rouibah et al., 2016; Wen et al., 2011). This finding confirmed that perceived enjoyment emerges as the most potent predictor of online shopping intentions. Thus, practitioners must ensure the customers' enjoyment, including aesthetic and lively features at their shopping. 
The present study findings revealed that perceived usefulness, perceived ease of use, attitude, and social value are positive and robust predictors of perceived enjoyment. These findings imply that customers' perceived enjoyment is the consequence of how costumers feel that the thing/object is valid, more accessible, and socially recognized. Interestingly these findings are new to the marketing literature, especially in the online shopping sector. Thus, practitioners must develop an online shopping system that enhances customers' positive attitude, perceived usefulness, perceived ease of use, and social recognition towards perceived enjoyment.

Finally, the study results showed that perceived enjoyment partially mediates between perceived usefulness, ease of use, social value, and online shopping intentions. In contrast, the influence of attitude on online shopping intentions is fully mediated by perceived enjoyment. These findings imply that perceived usefulness, ease of use, attitude, and social value with perceived enjoyment predict customers' online shopping intentions. Interestingly, these findings are new to the marketing literature, mainly online shopping intentions. Thus, practitioners must emphasize customers' perceived enjoyment, leading to online shopping intentions.

\section{Limitations and future research}

The present study's research model tested the technology acceptance model (TAM), including two other predictor variables- attitude and social value, and one mediator variable- perceived enjoyment. Thus, it is worth noting that the present study is the first to examine such an extended TAM in the online shopping context, leaving insightful implications in consumer behaviour.

Although this study has vast implications, it has several limitations that need to be addressed, creating opportunities for future research. First, this study collected data at a period, which was a biased data collection method. Thus, future researches could apply a longitudinal approach. Second, the present study has collected data from 20 to 60 years old people, which may result in biased data. This biasness may be avoided by future researchers considering children and older generation as respondents. Third, the current study approached convenience sampling technique, while future researchers should apply random sampling technique. Finally, the present study extended TAM, including attitude, social value, and perceived enjoyment. In contrast, future researches may include subjective norms, social norms, personal norms, and trust to measure customers' online shopping intentions.

\section{Peer-review:}

Externally peer-reviewed

\section{Conflict of interests:}

The author(s) has (have) no conflict of interest to declare.

\section{Grant Support:}

The authors declared that this study has received no financial support.

\section{Author Contributions:}

Idea/Concept/Design: A.A.H., Data Collection and/or Processing: S.M.S., Analysis and/or Interpretation: M.T.I., Literature Review: M.S.H., Writing the Article: A.A.H., Critical Review: A.A.H., Approval: A.A.H., S.M.S., M.T.I. 


\section{References}

Abdul-Muhmin, Alhassan G. 2010. "Repeat Purchase Intentions in Online Shopping: The Role of Satisfaction, Attitude, and Online Retailers' Performance." Journal of International Consumer Marketing 23(1):5-20.

Abdullah, Fazil, Rupert Ward, and Ejaz Ahmed. 2016. "Investigating the Influence of the Most Commonly Used External Variables of TAM on Students' Perceived Ease of Use (PEOU) and Perceived Usefulness (PU) of e-Portfolios." Computers in Human Behavior 63:75-90.

Ajzen, Icek. 1991. “The Theory of Planned Behavior." Organizational Behavior and Human Decision Processes 50(2):179-211.

Akhlaq, Ather, and Ejaz Ahmed. 2015. "Digital Commerce in Emerging Economies: Factors Associated with Online Shopping Intentions in Pakistan." International Journal of Emerging Markets.

Amin, Muslim, Sajad Rezaei, and Maryam Abolghasemi. 2014. "User Satisfaction with Mobile Websites: The Impact of Perceived Usefulness (PU), Perceived Ease of Use (PEOU) and Trust." Nankai Business Review International.

Amoako-Gyampah, Kwasi. 2007. "Perceived Usefulness, User Involvement and Behavioral Intention: An Empirical Study of ERP Implementation." Computers in Human Behavior 23(3):1232-48.

Anderson, James C., and David W. Gerbing. 1988. "Structural Equation Modeling in Practice: A Review and Recommended Two-Step Approach." Psychological Bulletin 103(3):411.

Ashraf, Abdul R., Narongsak Tek Thongpapanl, and Stavroula Spyropoulou. 2016. "The Connection and Disconnection between E-Commerce Businesses and Their Customers: Exploring the Role of Engagement, Perceived Usefulness, and Perceived Ease-of-Use." Electronic Commerce Research and Applications 20:69-86.

Bagozzi, Richard P., and Youjae Yi. 1988. "On the Evaluation of Structural Equation Models." Journal of the Academy of Marketing Science 16(1):74-94.

Biswas, Chhanda, Santus Kumar Deb, Abdulla Al-Towfiq Hasan, and Md Shariful Alam Khandakar. 2020. "Mediating Effect of Tourists' Emotional Involvement on the Relationship between Destination Attributes and Tourist Satisfaction." Journal of Hospitality and Tourism Insights.

Brizi, Ambra, Mauro Giacomantonio, Birga M. Schumpe, and Lucia Mannetti. 2015. "Intention to Pay Taxes or to Avoid Them: The Impact of Social Value Orientation." Journal of Economic Psychology 50:2231.

Cheema, Umair, Muhammad Rizwan, Rizwan Jalal, Faiza Durrani, and Nawal Sohail. 2013. "The Trend of Online Shopping in 21st Century: Impact of Enjoyment in TAM Model." Asian Journal of Empirical Research 3(2):131-41.

Chen, Mengdi, and Wan-Hao Zhang. 2021. "Purchase Intention for Hydrogen Automobile among Chinese Citizens: The Influence of Environmental Concern and Perceived Social Value." International Journal of Hydrogen Energy 46(34):18000-10.

Chiu, Chao-Min, Hua-Yang Lin, Szu-Yuan Sun, and Meng-Hsiang Hsu. 2009. “Understanding Customers' Loyalty Intentions towards Online Shopping: An Integration of Technology Acceptance Model and Fairness Theory." Behaviour \& Information Technology 28(4):347-60.

Cohen, Jacob. 1988. "Statistical Power." Analysis for the Behavioral Sciences 273-406.

Coppola, D. (2021, September 17). "E-commerce worldwide - statistics \& facts". Www.Statista.Com. https://www.statista.com/topics/871/online-shopping/.

Davis, Fred D. 1989. "Perceived Usefulness, Perceived Ease of Use, and User Acceptance of Information Technology." MIS Quarterly 319-40. 
Dickinger, Astrid, Mitra Arami, and David Meyer. 2008. "The Role of Perceived Enjoyment and Social Norm in the Adoption of Technology with Network Externalities." European Journal of Information Systems 17(1):4-11.

Fishbein, Martin, and Icek Ajzen. 1975. "Belief, Attitude, Intention and Behavior Reading, MA." AddisonWesley. Ford, RC \& Richardson, WD (1994). Ethical Decision Making: A Review of the Empirical Literature. Journal of Business Ethics 13:205-21.

Fornell, Claes, and David F. Larcker. 1981. "Structural Equation Models with Unobservable Variables and Measurement Error: Algebra and Statistics."

Giao, H., B. Vuong, and T. Quan. 2020. “The Influence of Website Quality on Consumer's e-Loyalty through the Mediating Role of e-Trust and e-Satisfaction: An Evidence from Online Shopping in Vietnam." Uncertain Supply Chain Management 8(2):351-70.

Gong, Wen, Rodney L. Stump, and Lynda M. Maddox. 2013. "Factors Influencing Consumers' Online Shopping in China." Journal of Asia Business Studies.

Hasan, A. A., Chhanda Biswas, Moumita Roy, Sonia Akter, and Bapon Chandra Kuri. 2020. "The Applicability of Theory of Planned Behaviour to Predict Domestic Tourist Behavioural Intention: The Case of Bangladesh." GeoJournal of Tourism and Geosites 31(3):1019-26.

Hasan, Abdulla Al-Towfiq. 2021. "Sustainable Customer Relationship Management (SusCRM) in Customer Loyalty Perspective: An Empirical Study on Restaurant Industries in Bangladesh." Global Media Journal 19(42):1-4.

Henseler, Jörg, Christian M. Ringle, and Rudolf R. Sinkovics. 2009. "The Use of Partial Least Squares Path Modeling in International Marketing." in New challenges to international marketing. Emerald Group Publishing Limited.

Henseler, Jörg, and Marko Sarstedt. 2013. "Goodness-of-Fit Indices for Partial Least Squares Path Modeling." Computational Statistics 28(2):565-80.

Holdack, Eric, Katja Lurie-Stoyanov, and Harro Fabian Fromme. 2020. "The Role of Perceived Enjoyment and Perceived Informativeness in Assessing the Acceptance of AR Wearables." Journal of Retailing and Consumer Services 102259.

Hsu, Chin-Lung, Judy Chuan-Chuan Lin, and Hsiu-Sen Chiang. 2013. "The Effects of Blogger Recommendations on Customers' Online Shopping Intentions." Internet Research.

Hu, Xi, Qian Huang, Xuepan Zhong, Robert M. Davison, and Dingtao Zhao. 2016. “The Influence of Peer Characteristics and Technical Features of a Social Shopping Website on a Consumer's Purchase Intention." International Journal of Information Management 36(6):1218-30.

Hu, Yong, Xin Sun, Jing Zhang, Xiangzhou Zhang, Fanghao Luo, and Lijun Huang. 2009. “A University Student Behavioral Intention Model of Online Shopping." Pp. 625-28 in 2009 International Conference on Information Management, Innovation Management and Industrial Engineering. Vol. 1. IEEE.

Jin, Seung-A. Annie. 2010. "The Effects of Incorporating a Virtual Agent in a Computer-Aided Test Designed for Stress Management Education: The Mediating Role of Enjoyment." Computers in Human Behavior 26(3):443-51.

Jolly, Eshin, Diana I. Tamir, Bethany Burum, and Jason P. Mitchell. 2019. “Wanting without Enjoying: The Social Value of Sharing Experiences." PloS One 14(4):e215318.

Ke, Chih-Horng, Huey-Min Sun, Yuan-Chi Yang, and Huey-Min Sun. 2012. "Effects of User and System Characteristics on Perceived Usefulness and Perceived Ease of Use of the Web-Based Classroom Response System." Turkish Online Journal of Educational Technology-TOJET 11(3):128-43.

Khare, Arpita, and Sapna Rakesh. 2011. "Antecedents of Online Shopping Behavior in India: An Examination." Journal of Internet Commerce 10(4):227-44. 
Kim, Changsu, Mirsobit Mirusmonov, and In Lee. 2010. "An Empirical Examination of Factors Influencing the Intention to Use Mobile Payment." Computers in Human Behavior 26(3):310-22.

Kim, HyeKyoung, and Jihoon Song. 2010. "The Quality of Word-of-mouth in the Online Shopping Mall." Journal of Research in Interactive Marketing.

Kim, Juyeon, Kyungmo Ahn, and Namho Chung. 2013. "Examining the Factors Affecting Perceived Enjoyment and Usage Intention of Ubiquitous Tour Information Services: A Service Quality Perspective." Asia Pacific Journal of Tourism Research 18(6):598-617.

Kucukusta, Deniz, Rob Law, Alia Besbes, and Patrick Legohérel. 2015. "Re-Examining Perceived Usefulness and Ease of Use in Online Booking: The Case of Hong Kong Online Users." International Journal of Contemporary Hospitality Management.

Lim, Yi Jin, Abdullah Osman, Shahrul Nizam Salahuddin, Abdul Rahim Romle, and Safizal Abdullah. 2016. "Factors Influencing Online Shopping Behavior: The Mediating Role of Purchase Intention." Procedia Economics and Finance 35:401-10.

Lin, Pei-Chun, and Yi-Hsuan Huang. 2012. "The Influence Factors on Choice Behavior Regarding Green Products Based on the Theory of Consumption Values." Journal of Cleaner Production 22(1):11-18.

Manis, Kerry T., and Danny Choi. 2019. "The Virtual Reality Hardware Acceptance Model (VR-HAM): Extending and Individuating the Technology Acceptance Model (TAM) for Virtual Reality Hardware." Journal of Business Research 100:503-13.

Oliver, Jason D., and Seung-Hee Lee. 2010. "Hybrid Car Purchase Intentions: A Cross-cultural Analysis.” Journal of Consumer Marketing.

Osborne, Jason W., and Anna B. Costello. 2004. "Sample Size and Subject to Item Ratio in Principal Components Analysis." Practical Assessment, Research, and Evaluation 9(1):11.

Ozturk, Ahmet Bulent, Anil Bilgihan, Khaldoon Nusair, and Fevzi Okumus. 2016. "What Keeps the Mobile Hotel Booking Users Loyal? Investigating the Roles of Self-Efficacy, Compatibility, Perceived Ease of Use, and Perceived Convenience." International Journal of Information Management 36(6):1350-59.

Patel, Vipul, Kallol Das, Ravi Chatterjee, and Yupal Shukla. 2020. "Does the Interface Quality of Mobile Shopping Apps Affect Purchase Intention? An Empirical Study." Australasian Marketing Journal (AMJ) 28(4):300-309.

Pitafi, Abdul Hameed, Shamsa Kanwal, and Ali Nawaz Khan. 2020. "Effects of Perceived Ease of Use on SNSs-Addiction through Psychological Dependence, Habit: The Moderating Role of Perceived Usefulness." International Journal of Business Information Systems 33(3):383-407.

Purnawirawan, Nathalia, Patrick De Pelsmacker, and Nathalie Dens. 2012. "Balance and Sequence in Online Reviews: How Perceived Usefulness Affects Attitudes and Intentions." Journal of Interactive Marketing 26(4):244-55.

Ramayah, T., and Joshua Ignatius. 2005. "Impact of Perceived Usefulness, Perceived Ease of Use and Perceived Enjoyment on Intention to Shop Online." ICFAI Journal of Systems Management (IJSM) 3(3):36-51.

Rouibah, Kamel, Paul Benjamin Lowry, and Yujong Hwang. 2016. “The Effects of Perceived Enjoyment and Perceived Risks on Trust Formation and Intentions to Use Online Payment Systems: New Perspectives from an Arab Country." Electronic Commerce Research and Applications 19:33-43.

So, Kevin Kam Fung, Hyunsu Kim, and Haemoon Oh. 2020. "What Makes Airbnb Experiences Enjoyable? The Effects of Environmental Stimuli on Perceived Enjoyment and Repurchase Intention." Journal of Travel Research 0047287520921241.

Sohn, Stefanie. 2017. "A Contextual Perspective on Consumers' Perceived Usefulness: The Case of Mobile Online Shopping." Journal of Retailing and Consumer Services 38:22-33. 
Tandon, Urvashi, Ravi Kiran, and Ash N. Sah. 2016. "Customer Satisfaction Using Website Functionality, Perceived Usability and Perceived Usefulness towards Online Shopping in India." Information Development 32(5):1657-73.

Taylor, Shirley, and Peter Todd. 1995. "Decomposition and Crossover Effects in the Theory of Planned Behavior: A Study of Consumer Adoption Intentions." International Journal of Research in Marketing 12(2):137-55.

Teo, Timothy, and Jan Noyes. 2011. “An Assessment of the Influence of Perceived Enjoyment and Attitude on the Intention to Use Technology among Pre-Service Teachers: A Structural Equation Modeling Approach." Computers \& Education 57(2):1645-53.

Tong, Xiao. 2010. "A Cross-national Investigation of an Extended Technology Acceptance Model in the Online Shopping Context." International Journal of Retail \& Distribution Management.

Ventre, Ivan, and Diana Kolbe. 2020. "The Impact of Perceived Usefulness of Online Reviews, Trust and Perceived Risk on Online Purchase Intention in Emerging Markets: A Mexican Perspective." Journal of International Consumer Marketing 32(4):287-99.

Vijayasarathy, Leo R. 2004. "Predicting Consumer Intentions to Use On-Line Shopping: The Case for an Augmented Technology Acceptance Model." Information \& Management 41(6):747-62.

Wang, Yi-Shun, Hsin-Hui Lin, and Yi-Wen Liao. 2012. "Investigating the Individual Difference Antecedents of Perceived Enjoyment in Students' Use of Blogging." British Journal of Educational Technology 43(1):139-52.

Wen, Chao, Victor R. Prybutok, and Chenyan Xu. 2011. "An Integrated Model for Customer Online Repurchase Intention." Journal of Computer Information Systems 52(1):14-23.

Wu, Wei, Vivian Huang, Xiayu Chen, Robert M. Davison, and Zhongsheng Hua. 2018. "Social Value and Online Social Shopping Intention: The Moderating Role of Experience." Information Technology $\mathcal{E}$ People.

Yoon, Cheolho. 2009. "The Effects of National Culture Values on Consumer Acceptance of E-Commerce: Online Shoppers in China." Information \& Management 46(5):294-301.

Zendehdel, Marzieh, Laily Hj Paim, and Syuhaily Bint Osman. 2015. "Students' Online Purchasing Behavior in Malaysia: Understanding Online Shopping Attitude." Cogent Business \& Management 2(1):1078428. 